Mercy amid Terror? The Role of Amnesties during Russia's Civil War

\author{
Matthew Rendle
}

\begin{abstract}
Russia's civil war was a period of escalating violence as the Bolsheviks struggled to retain power, yet it was also a period of numerous amnesties. This article analyses the nature and impact of these amnesties, and explores their value to the Bolsheviks. These amnesties were not a sign of mercy; they never admitted mistakes or granted innocence, but excused or underplayed crimes and their significance. Instead, amnesties had a range of practical and political functions for the state, not least of which was to act as a 'safety valve' to release burgeoning pressures on the fledgling justice system and tensions between state and society.
\end{abstract}

Biography

Matthew Rendle is Lecturer in History at the University of Exeter. 


\title{
Mercy amid Terror? The Role of Amnesties during Russia's Civil War
}

\author{
Matthew Rendle
}

Russia's civil war was a period of escalating violence as the Bolsheviks struggled desperately to maintain their hold on power. Horrific tales of acts of terror dominate contemporary accounts and the Bolsheviks' ruthlessness undoubtedly played a significant role in their victory. Yet this period, one of the most violent in Russia's history, also saw one of the greatest frequencies of amnesties. One study has noted eleven official amnesties between 1918 and 1921 in Russia, ${ }^{1}$ but in reality there were more, especially if the territory of the former Russian empire is included. Some amnesties released entire categories of criminals, whilst others targeted particular social or political groups, or related to specific crimes or localities. The most frequent and wide-ranging were what one scholar has referred to as 'hybrid amnesties'; they released certain types of criminals and reduced punishment for others. ${ }^{2}$ Overall, amnesties benefitted tens of thousands of people, even as violence continued to increase.

This article analyses the nature and impact of these amnesties, exploring their purpose and value to the Bolsheviks. The texts of amnesty decrees reveal little about the state's intentions beyond noting that the Bolsheviks were in a position of relative strength and able to dispense mercy to their enemies, displaying the 'humane' nature of the proletarian state. Newspapers provided little additional commentary when they published the decrees and there was little discussion in contemporary publications until after 1922. Then legal theorists extended earlier points; amnesties reflected communist 'humanity', delivering mercy to workers and peasants who had inadvertently committed crimes through a lack of consciousness, material hardship or pressure from anti-Bolshevik forces. ${ }^{3}$ That the proletarian state issued amnesties rather than an individual (the tsar) as before enabled such flexibility 
and sensitivity. ${ }^{4}$ Some jurists provided retrospective justification based on broader views of crime and punishment. B. S. Utevskii, for example, argued that crime was socially dangerous and that punishment corresponds to the level of that danger. If the level of danger changes, whether due to changes in a person's character or socio-political circumstances, the punishment should change. This was fair and permitted people who were no longer dangerous to return to socially useful work. ${ }^{5}$

There was no such justification provided during the civil war, however, either publicly or privately. Why then did the state issue so many amnesties in this period? Did they reflect mercy or broader understandings of crime and punishment? Were they an attempt to educate or rehabilitate? Or were amnesties forced on the state by practical concerns? These questions have rarely been addressed by historians. Soviet legal histories ignored amnesties, whilst a few specialist studies reiterated the claims of mercy made by contemporaries and did not analyse how amnesties operated in practice. ${ }^{6}$ Western studies have focused on repression, making only passing mentions of civil war amnesties and proposing various motivations, from benevolent (and largely symbolic) acts designed to improve the state's image, to part of the re-centralization of authority, to a need to reduce the prison population. ${ }^{7}$

This article argues that amnesties were applied systematically by officials at all levels driven by directives from the state. Examining the implementation of amnesties, moreover, reveals that even individuals who were excluded on paper often benefitted in practice as the state encouraged officials to apply amnesties generously. This complicates the usual view of the civil war as a period of uninterrupted violence; in reality, the interaction of justice (as represented by amnesties) and violence was complex.

The purpose of amnesties, as with the justice system generally, was multifaceted. They acted as a crucial 'safety valve', ${ }^{8}$ relieving pressure on overstretched courts and prisons, and reducing tensions between state and society. This impact may have been short-lived, and 
a reduction or increase in repression could have had a similar effect, but both were deemed undesirable. Whilst the former was considered too risky, the latter was increasingly seen to have a limited impact. Strictly enforcing decrees on food requisitioning, taxes, private trade or desertion required the arrest of innumerable people, something far beyond the scope of a fledgling security apparatus fighting threats on a number of fronts. As it was, thousands were investigated and arrested. Amnesties relieved these pressures and, by frequently targeting lower social groups, provided substance to the state's claims to be a workers' and peasants' government, and they were compatible with arguments surrounding the causes of crime and the role of punishment. They removed temporarily the need to prosecute particular crimes and released people without admitting to mistakes that would undermine the authority of courts. People had still committed crimes, but for condonable reasons. Finally, in tandem with the New Economic Policy (NEP) after 1921, amnesties helped draw a line under the civil war and establish a post-conflict equilibrium between state and society.

This article analyses amnesties through their impact on revolutionary tribunals in European Russia, with some use of material from other courts and from across the former Russian Empire. ${ }^{9}$ The Decree on Courts, published on 24 November 1917, created tribunals to judge counter-revolutionary threats, profiteering, speculation, sabotage and other 'political' crimes, rather than 'normal' crimes such as murder or theft, which were left to people's courts. The first cases were heard in December in Petrograd and most provincial towns had their own tribunals by spring 1918. In May 1918, a supreme tribunal was created in Moscow under the All-Russian Central Executive Committee of the Congress of Soviets (VTsIK), which came to supervise all civilian tribunals. In late 1918 and 1919, tribunals were also established across the military and the transport network. Initially, these new tribunals answered to the military authorities and the Commissariat of the Means of Communications respectively. In March 1920, however, all tribunals were placed directly under the authority of 
VTsIK. This basic structure remained until 1922 when civilian tribunals were abolished. Tribunals have been seen to epitomize the use of the justice system to implement political violence so their adoption of amnesties emphasizes the existence of a more complex picture. Tribunals also dealt with a wider range of crimes than their mandate suggested as most crimes were 'political' in some sense, thus allowing broad insights into amnesties. Nonetheless, amnesties were also applied by people's courts (which dealt with many more crimes) and other organs that dispensed sentences (most obviously, the secret police or Cheka). The scale and impact of amnesties, therefore, was even greater than argued below.

\section{$\underline{\text { The Amnesty Decrees }}$}

Amnesties were a feature of Russian history prior to the Bolsheviks' seizure of power in October 1917. Muscovy saw many, from the genuinely merciful to the cynically deceptive. ${ }^{10}$ They continued to a lesser extent in Imperial Russia, culminating in an amnesty as part of the Romanov tercentenary celebrations in 1913. The expectation among liberal and moderate elements in society that an amnesty would be issued suggests that they remained common at such times. ${ }^{11}$ Equally, one of the first acts of the Provisional Government after taking power during the February Revolution was to issue a celebratory amnesty for political prisoners. ${ }^{12}$

The Bolsheviks did not issue an amnesty on taking power, but amnesties remained associated with celebration. The first amnesties in Soviet Russia came when at least two local authorities felt that it would be an obvious way of celebrating the first anniversary of the

February Revolution. Bezhetskii uezd soviet (Tver' province) amnestied those imprisoned for 'unimportant' crimes (mainly theft), entrusting the task to its investigative commission. Twenty-four people were released, ten of whom had been in prison since before the October Revolution. The local prison authorities were uneasy, informing the national board for prisons 
who, in turn, asked Commissariat of Justice (Narkomiust) whether it was legal for local authorities to release those guilty of what it saw as 'important' crimes. Narkomiust replied that it was not and ordered the prosecution of the commission, but the matter was dropped once it became clear that various local authorities were complicit. ${ }^{13}$ A similar amnesty in Timskii uezd (Kursk province) prompted the same reaction from Narkomiust. ${ }^{14}$

More significant was the amnesty issued in Petrograd as part of the May Day celebrations in 1918. The circumstances remain vague. City officials seem to have wanted to regain public support and ease overcrowded prisons, which were causing problems with food, housing and disease, as well as antagonizing Kronstadt sailors, whose base was used as an overflow. The situation was so desperate by January 1918 that Lenin recommended that a third to a half of all prisoners should be transferred to provincial prisons where food supplies were better. ${ }^{15}$ This did not occur and officials considered alternatives, deciding on an amnesty on 27 April. At the Congress of Soviets of the Northern Region (which included Petrograd) on 29 April, the city's party leader, G. E. Zinov'ev, argued that individual opponents no longer posed a threat, and had been defeated by workers and peasants who did not wish to treat their enemies in the same manner as bourgeois states. ${ }^{16}$ Eighty-four delegates voted for an amnesty, seventeen against and fifteen abstained. The proposal was then passed by Petrograd's soviet. ${ }^{17}$ The amnesty freed all prisoners with less than six months left, those who had committed political crimes, those over seventy years old and halved the sentences of serious cases. It excluded bribe-takers, traitors and speculators and had several other caveats. It covered all crimes committed before 1 May, even if not yet resolved. ${ }^{18}$

Narkomiust was dismayed, fearing that the last few months' work would be undone and demanded that obvious counter-revolutionaries were excluded. ${ }^{19}$ Petrograd officials were defensive, claiming that the initiative had come from local legal organs and that the amnesty would free no more than fifteen people, mainly those involved in an anti-soviet plot led by V. 
M. Purishkevich, a notorious monarchist, none of whom had more than two months left on their sentences. ${ }^{20}$ In truth, these individuals had years left on their sentences and the amnesty freed many more people. A Menshevik newspaper estimated that around two hundred would benefit, many of whom were criminals or high-profile enemies who deserved imprisonment, like Purishkevich. ${ }^{21}$ Case files prove that the amnesty was widely invoked. Broad definitions of what constituted a 'political' crime enabled many to claim eligibility successfully. Some stopped contesting their case, instead noting that the accusations, even if incorrect, fell within the amnesty's terms. ${ }^{22}$ The numbers were sufficient for Petrograd's tribunal to produce a preprinted release form to ease the process, with a gap for the defendant's name above a generic statement that the defendant should be released under the amnesty. ${ }^{23}$

Rumours spread that the amnesty would be extended to the whole country. ${ }^{24}$ It was not, but it was reported in local papers, ${ }^{25}$ and some authorities followed Petrograd's lead. In early June, legal officials in Penza proposed publishing Petrograd's amnesty verbatim, arguing that it would lead to a 'significant reduction' in their workload, but they faced 'mass opposition' led by the local Cheka. Instead, the officials asked the government to extend the amnesty. ${ }^{26}$ The same occurred in Siberia, whilst elsewhere the authorities in Arkhangel'sk did adopt Petrograd's amnesty. ${ }^{27}$ Narkomiust was livid: a dubious amnesty was spreading and, equally worryingly, local authorities were acting independently just as the state was trying to strengthen control from Moscow. On 6 June, responding to the Siberian proposal, Narkomiust stated that only the central authorities could issue amnesties. ${ }^{28}$ This order was repeated by P. I. Stuchka, then Commissar of Justice, at a congress of local justice officials on 6 July when he declared that the state was focused on expediency not mercy. Petrograd's amnesty had freed 'undesirables' who should be in prison, whilst others had released robbers. There must be no more local amnesties. ${ }^{29}$ A few days later, the new constitution reinforced his point; only the Congress of Soviets and VTsIK could issue amnesties. ${ }^{30}$ 
This power was exercised on 6 November 1918. At the Sixth All-Russian Exceptional Congress of Soviets, L. B. Kamenev, a senior party figure, proposed a national amnesty, coinciding with the anniversary of the October Revolution. The proletarian state was strong enough, he argued, to show 'mercy' to those prepared to lay down their arms and recognize its authority. ${ }^{31}$ All those arrested on suspicion of being involved with plots or oppositional groups would be released if their guilt was not proven within two weeks. All hostages would be freed (a common practice during the civil war to combat organized resistance) except where they were held in response to hostages seized by opponents. Finally, all courts would re-examine all cases with a view to releasing those who did not endanger the state. VTsIK was responsible for organizing the amnesty, with soviets taking over locally. The scale of the struggle was emphasized and the need for harsh measures, but that the Red Army's success permitted mercy. The word 'amnesty' was not used in the decree, but it was in Izvestiia and Pravda, who both printed the text in full. ${ }^{32}$

The regime may have been trying to diffuse the criticism that surrounded its policy of 'red terror' after 5 September following an attempt on Lenin's life. Kamenev stated that an amnesty would combat the 'lies and libel' spreading in Russia and the western press about the Cheka's activities and methods. ${ }^{33}$ Cheka leaders themselves noted later in a private meeting that the amnesty would help convince those wavering in their support. ${ }^{34}$ Tensions between state and society had grown throughout 1918; there was opposition to the reintroduction of the death penalty in June, rising support for rival socialist parties, frequent revolts, and more arrests from a wider range of social groups. The regime probably felt the need to ease these tensions, whilst the text promised that the amnesty would regulate judicial organs to ensure they worked in a rational and fair manner, targeting only real enemies.

Yet this decree was not as generous on paper as the Petrograd amnesty: most prisoners would have their guilt proven within a fortnight; the categories of eligible crimes were vague; 
and terror continued. Moreover, on 15 November, the presidium of the Cheka demanded that provocateurs, former tsarist police and officials, Black Hundred activists, spies, saboteurs, counter-revolutionary agitators (particularly priests, officials and those in the Red Army) and those convicted for stealing explosives and arms were excluded. VTsIK agreed. ${ }^{35}$

Nonetheless, amnesties became a regular act after November 1918 for the rest of the civil war; one formed an important part of the anniversary celebrations of the October Revolution, whilst another was issued around April-May each year, although not always tied to the May Day celebrations. Additional amnesties focused on specific crimes. Broadly speaking, several trends are visible. First, amnesties became more generous, possibly as the various bodies involved became used to them and less fearful of their consequences. Second, Narkomiust took responsibility for them as part of the greater centralization of legal affairs and state matters more generally, leading to greater regulation and the creation of instructions on their implementation. Finally, some groups fared better than others in each amnesty, indicating the state's changing concerns across this period.

These trends were visible in three amnesties issued in 1919. On 23 February 1919, an amnesty celebrated the first anniversary of the creation of the Red Army. It released all those involved in disorder and mass crimes as long as these did not have a 'white guard' character, or involve robbery, rape or arson; all those imprisoned for first-time desertion; all those guilty of ill-discipline (if not part of a white guard plot); and all those imprisoned for military crimes who agreed to return to service in the Red Army. ${ }^{36}$ On 25 April, another amnesty urged courts to re-examine cases again and release those no longer posing a danger. This decree was directed at workers and peasants caught up in the escalating unrest. All those who were not organizers, instigators or leaders, but became involved through a lack of 'consciousness', should be released, as should those involved in unorganized unrest. ${ }^{37}$ Finally, on 5 November, there was an extensive two-part amnesty marking the second anniversary of the October 
Revolution. The main decree released all prisoners except those involved in plots or armed struggle, or who had committed 'selfish' crimes for personal gain [korystnye prestupleniia]. Those ineligible but with sentences of over five years' imprisonment would see them reduced to five years. Deserters sentenced to death would have this reduced to five years in prison. Deserters with lesser sentences were given the option, if repentant, to accept a fine and return to the front, whilst those on the run would be pardoned if they gave themselves in by 25 November. Local commissions were created to implement the amnesty with representatives from the soviet, Cheka and tribunals, whilst Narkomiust took national responsibility. Another decree on the same day amnestied imprisoned members of rival political parties if they were willing to defend the state, unless they had actively participated in counter-revolution. ${ }^{38}$

As amnesties became more complex, local officials struggled to enact them correctly. Some turned to Narkomiust with queries; some proceeded on the basis of mistaken interpretations; others became mired in confusion. Narkomiust produced instructions from November 1919 to clear up misunderstandings; it clarified that 'selfish' crimes included speculation and the dereliction of duties, and gave guidance on altering prison sentences. It also provided a timescale: commissions enacting the amnesty should finish by December, although courts had another month to re-examine their cases. ${ }^{39}$ The queries continued, though, as officials still found subsequent decrees confusing. ${ }^{40}$ The fact that local courts issued a wider range of sentences than Narkomiust expected or condoned exacerbated confusion, creating categories of prisoners whose status under various amnesties was unclear. Various central justice organs provided increasing clarity as they sent successive decrees to local officials, structuring instructions around lists of crimes or the various stages in the legal process, detailing the required action in each case. ${ }^{41}$ In November 1922, ten thousand copies were printed of a booklet containing the amnesty, instructions and relevant information. ${ }^{42}$ 
The November 1919 amnesty set the tone for the future. The blanket reduction of sentences, irrespective of the seriousness of the crime, was extended in future amnesties. Policies on deserters were repeated, betraying concern over staffing the fledgling Red Army. Along with the focus on workers and peasants, this was no doubt designed to convince people that the state remained their 'proletarian' government despite repressive supply and conscription policies. The olive branch held out to political opponents was an attempt to undermine support for rival parties as internal debates grew within them over how they should act as the civil war intensified. All this reflected the use of amnesties as a tool to help tackle current political problems.

The amnesties of $1920-2$ were variations of the 1919 model. ${ }^{43}$ Counter-revolutionaries (active participants in the war) remained excluded as, increasingly, were bandits, professional thieves and repeat offenders. The theme of redemption appears more frequently, particularly for potentially productive individuals; the amnesty on 1 May 1920, for example, urged the release of all those willing to participate in the economic struggle to redeem their crimes. In contrast, recidivists were unproductive and irredeemable. In May 1920, 'harmful' speculators were excluded, but a year later, after the start of the NEP in March 1921 had initiated a new tax in kind on peasants, an amnesty on 29 April focused exclusively on those sentenced for not fulfilling food quotas or paying taxes, and for trading (speculating) in food, raw materials and fodder. This amnesty aimed to demonstrate that the Bolsheviks were serious about the NEP by offering mercy to those convicted under former policies. Moreover, as the November 1922 amnesty clarified, the state increasingly distinguished between crimes committed due to material need, as much so-called speculation had been, and crimes committed for profit. Most obviously, profitable activities surrounding the production, sale and trade of illegally-brewed alcohol were firmly excluded from amnesties. 
By 1921, victory in the civil war was becoming assured and amnesties reflected the need to come to terms with the war's legacy. ${ }^{44}$ Thus, as well as the more nuanced view of speculation, an amnesty was offered on 3 November 1921 for workers and peasants who fought in the White armies and were now in prison or exile. A day later, an amnesty was offered to workers and peasants involved in the Kronstadt Revolt. Views of banditry also became more flexible, with a focus on leaders or organizers, rather than the masses involved. The Bolsheviks used terms that refuted any change of policy; for example, people who had been 'deceived' into fighting for the Whites would be shown mercy, as would those whose 'lack of consciousness' led to their involvement in revolts. But the end result was a desire to ease growing conflict between state and society, ${ }^{45}$ something also evident in the instructions to the November 1922 amnesty. These highlighted twenty-five areas affected by famine in 1921-2 and encouraged officials there to release those convicted of crimes such as theft and speculation, irrespective of their sentences. ${ }^{46}$

Later amnesties were also more precise. The November 1921 amnesty was typical, releasing all those with less than a year remaining in prison; halving the sentences of those with 1-3 years remaining; reducing by a third those with 3-5 years left; and capping the maximum sentence at five years. The death penalty was often changed to five years in prison. Instructions accompanying the amnesty described how specific crimes should be treated. Narkomiust seemed to be trying to make implementing amnesties an objective process, leaving no room for local initiative and thus inconsistencies. In 1922, new criminal law codes enabled Narkomiust to refer to standard definitions of crimes.

All of the above amnesties were issued in Moscow, but amnesties were also issued by fledgling soviet governments in newly-established autonomous regions from 1919 onwards. ${ }^{47}$ These followed a similar template to Moscow, although there were always slight differences. Some regions saw amnesties as an opportunity to assert independence and facilitate the state- 
building process. In Georgia, a May Day amnesty in 1921 promising to pardon all those who had formerly opposed it was entitled 'Decree No. 1', suggesting that it was seen as the foundation stone of the new republic. ${ }^{48}$ Similarly, the timing of Ukrainian amnesties - in October to coincide with its annual congress of soviets rather than November - was intended to emphasize that amnesties served their concerns not Moscow's. ${ }^{49}$

Moscow reacted differently to these amnesties. It was happy to publish Ukrainian amnesties in newspapers and help enact them where possible, ${ }^{50}$ but a debate erupted when Turkestan published an amnesty in November 1921 without the authorization of VTsIK. VTsIK wanted to preserve its authority across all republics and the supreme tribunal also wanted the power to sanction it, as they did other amnesties. ${ }^{51}$ Moscow also acted when areas of confusion emerged, particularly in military and railway tribunals, whose jurisdiction often crossed boundaries. After the Ukrainian amnesty in May 1920, the main railway tribunal asked whether this affected railways running into the Ukraine. ${ }^{52}$ In November 1921, Orenburg military tribunal, whose jurisdiction stretched across the Kirgiz border, asked Narkomiust which amnesty to apply. ${ }^{53}$ Moscow asserted its authority both times. Narkomiust regarded these amnesties as another challenge to its attempts to centralize authority, but it could do little once republics had established their own state apparatus and court systems.

\section{$\underline{\text { Implementation and Impact }}$}

Amnesties only mattered, of course, if they were actually implemented and the archives reveal that amnesties were applied systematically by organs at all levels, encouraged repeatedly by VTsIK and Narkomiust. And, surprisingly, amnesties were more generous in practice than on paper. As has been seen, many local soviets believed amnesties would benefit their own activities, whilst others quickly adjusted to the state's changing stance on amnesties during 
1918. The justice department in Moscow province, for instance, rejected on 24 October 1918 a proposal by local courts for an amnesty to celebrate the forthcoming anniversary of the October Revolution, no doubt influenced by the official line on amnesties at this stage. ${ }^{54}$ However, it quickly implemented the amnesty instigated by VTsIK a fortnight later. Records suggest that over seventy-six benefitted, most accused of counter-revolutionary activities, including misuse of official power, undermining authority, drunkenness and hooliganism. A few - including speculators, murderers and saboteurs - benefitted from the nebulous section in VTsIK's decree permitting the release of those who no longer posed any danger to the state, which would have otherwise been easy to dismiss as purely symbolic. ${ }^{55}$

A year later, Tula's officials played out a by-then typical scenario. The amnesty of 5 November 1919 was discussed by justice officials in the provincial soviet on 12 November. As instructed by Narkomiust, a temporary commission was formed to enact the amnesty ten days later. It asked for clarification on certain points, but by the end of the month, as required officially, it claimed to have re-examined the cases of most inmates in the provincial prison to determine eligibility. ${ }^{56}$ By 1920-1, provinces routinely established commissions involving all relevant bodies - local departments of justice, people's courts, tribunals, the Cheka, prison officials - to implement amnesties and review problematic cases. ${ }^{57}$ Amnesties were published in local newspapers and provincial organs often reissued key elements, such as the reductions in sentences, for distribution within the province. ${ }^{58}$

Amnesties could be enacted at the end of a trial, after guilt had been confirmed and a sentence pronounced, or they could be applied later. Courts were supposed to re-examine all existing cases after an amnesty, but were often prompted by appeals from defendants or their lawyers. If a defendant felt that a decision was incorrect, they often protested and the case would go to the cassation department of the supreme tribunal, with the decision confirmed by the presidium of VTsIK. As it was responsible for amnesties, Narkomiust also responded to 
appeals sent to it directly. In addition, the supreme tribunal asked to see the results of each tribunal's decisions on amnesties, which took the form of long lists of individuals, crimes and resolutions. If anything in these lists seemed irregular, the supreme tribunal intervened, asking for the decision to be reviewed or altered. Narkomiust did the same for any questionable decisions that came to its attention.

I have not found comprehensive statistics on those benefiting from amnesties in these years. ${ }^{59}$ Narkomiust requested information on amnesties from local justice officials so there are statistics on the impact of particular amnesties in individual provinces. A sense of scale can also be gained from the incomplete lists gathered by the supreme tribunal. Ultimately, however, the impact of each amnesty varied across Russia for no discernible reason, although local efficiency (both in terms of implementing amnesties and keeping accurate records) and local crime rates no doubt played a role. Provinces close to the military fronts of the civil war, for instance, faced greater pressures from desertion, food supply revolts and speculation, sentenced more people for these crimes, and thus more were eligible for amnesties.

Variations in impact were evident in the reports to Narkomiust on the November 1919 amnesty. In Perm', 613 of 1,022 prisoners (60 per cent) were freed, whilst thirty-nine had their sentences reduced and ten were refused amnesty because they still posed a danger to the state. In Kazan', 462 were released, fifty-five received shorter sentences and ten were refused; in Riazan', the figures were 221, seventeen and eighteen respectively. In Ekaterinburg, the tribunal freed twenty-five, eased the sentences of eight, refused amnesty to 143 and ended 138 investigations, whilst people's courts released 152, eased ninety-one sentences and refused amnesty to seventeen. In Orel, seventy-seven of ninety-three (83 per cent) imprisoned by tribunals were freed, five had their sentences reduced and eleven were refused. In Briansk, thirty-nine from fifty imprisoned by tribunals were freed (78 per cent), with eight reduced sentences and three refused. ${ }^{60}$ A year later in November 1920, Perm's tribunal considered 
1,135 cases. From these, 192 cases (17 per cent) were affected: investigations into eighty-six (involving 203 individuals) were stopped, whilst 106 (involving 231 people) were reviewed. Seventy-seven people were freed, seventy-four had their sentences reduced by two-thirds and forty had them reduced by a third. Forty were refused amnesty. Almost 83 per cent of those sentences reviewed benefited. ${ }^{61}$ Another year on, Arkhangel'sk's tribunal sentenced 303 individuals from 1 January to 1 July 1921 of whom only twenty-nine (9.6 per cent) qualified for the November 1921 amnesty. ${ }^{62}$ These statistics suggest that many authorities did reconsider every case, as instructed, and that thousands benefited, especially as the pressure from Narkomiust to implement amnesties increased over time. These figures are also just from tribunals: many more sentenced by people's courts and the Cheka benefitted. ${ }^{63}$

It is also clear that amnesties were applied to a wide range of crimes. Arkhangel'sk's provincial camp for forced labour, for example, compiled a list of twenty-four individuals eligible for amnesty in November 1920. Their crimes included sympathizing with the Whites, desertion, theft, banditry, illegal brewing, corruption, speculation and being a 'harmful element'. All had their sentences reduced. ${ }^{64}$ Banditry, in particular, was condemned across this period, yet those convicted of it were amnestied. Perhaps their involvement was seen to reflect a lack of consciousness, but disparities can be seen across tribunals. Some refused to discuss amnesty in cases of banditry, or even crimes such as desertion or murder; others applied amnesties to all crimes. Officials had to be careful. In July 1922, the Kalmytskii region was allowed to offer an amnesty for bandits to encourage people to return to 'peaceful' work after large-scale unrest, but Moscow prosecuted several officials for exceeding the terms of this amnesty by allowing the release of known leaders. ${ }^{65}$

The most comprehensive statistics available chart the impact of the November 1920 amnesty on ninety military tribunals. In total, 23,669 individuals benefitted from the amnesty; 71.8 per cent of whom had been sentenced with the rest still under investigation. 61.3 per cent 
were freed completely, 11.6 per cent received conditional freedom and 27.1 per cent had their sentences reduced. Of the latter, most (36.6 per cent) received a reduced sentence of five years (although 7.5 per cent remained with higher sentences), whilst of the 55.9 per cent with lower sentences, the majority had them reduced by a half or two-thirds. 77.8 per cent of these decisions were made in procedural rather than legal meetings of the tribunal and it was the first time that 96.5 per cent of cases had been submitted for amnesty. ${ }^{66}$

The final figures reveal two notable parts of the broader process. First, for 3.5 per cent of individuals, it was the second time (or more) that their case had been considered. Cases were re-examined under successive amnesties. Those initially refused were often declared eligible for a subsequent amnesty. The terms changed over time, as did the state's concerns. Most obviously, former tsarist-era provocateurs were pursued by the authorities immediately after the October Revolution and were usually refused amnesty, but as the civil war intensified, they appeared less threatening and, consequently, were often released under later amnesties. ${ }^{67}$ Equally, although some amnesties stipulated whether or not someone was eligible who had already received a reduced sentence from a previous amnesty, others did not, and individuals had their sentences reduced in stages by successive amnesties, often at the urging of the supreme tribunal. ${ }^{68}$ It was even possible to apply multiple amnesties at the same time. P. V. Platonov was sentenced to two years in prison on 29 December 1922 for a crime committed on 14 January 1921. This could be immediately halved using the November 1921 amnesty as the crime had been committed beforehand, leaving less than a year's sentence, which made Platonov eligible for release under the November 1922 amnesty. ${ }^{69}$

The second notable point was that most cases were reviewed by procedural meetings. As mentioned, the instructions issued alongside amnesties reflected Narkomiust's desire to remove arbitrariness on the part of local courts, turning amnesties into an administrative process where cases were assessed for their eligibility on types of crimes committed rather 
than analysing the particulars of individual cases. Thus, amnesty records are often terse, providing little evidence of any discussion about the relative threats posed by different crimes or the role of different types of sentences. On 23 December 1918, a prosecutor wrote in his rebuttal to a defendant's appeal that it was 'strange' that the tribunal had granted amnesty in a case of blackmail and corruption by an official without considering whether those concerned posed a danger to the revolution. ${ }^{70}$ As time passed, however, such comments disappeared and it became clear to all concerned that the amnesty process was largely administrative.

Later amnesties did offer scope for judgement when deciding what was a 'conscious' action or what constituted a 'selfish' crime. Only occasionally, though, do records reveal the decision-making process. On 18 May 1920, Penza's provincial tribunal heard the case of eight peasants accused of seizing livestock from poorer peasants and other crimes. All had their sentences reduced under the amnesties of November 1919 and May 1920 apart from one - the person who initiated the crimes. His actions were deemed deliberate and more serious. ${ }^{71}$ When asked to reconsider a case by VTsIK in May 1920, Novgorod's tribunal again rejected an amnesty due to the 'malicious' character of the defendants, who had engaged in systematic speculation. ${ }^{72}$ On 21 November 1922, the military tribunal in Tashkent sentenced a man to death for illegally purchasing cartridges from soldiers. He was ineligible for amnesty, it stated, as 'professional' purchaser of weapons for criminal use. ${ }^{73}$ A debate over the fate of seventeen deserters in the organizational-instructional department of the military college of the Supreme Court on 20 April 1923 questioned the November 1922 amnesty's lenient stance on deserters. Leniency was proclaimed, but only after a long debate on the nature of desertion indicated unease; the euphoria of military victory, officials noted, could not conceal the seriousness of desertion as a crime. ${ }^{74}$ Yet ultimately, as with most cases, the only judgement open to them was assigning a crime to a category in the amnesty and then implementing the instructions assigned to that category, even if they disagreed. 
Yet the bureaucratic nature of the process should not mask a key message; all courts were expected to enact amnesties. Instructions read more as exhortations to act than attempts at limitation. Later instructions on the November 1920 amnesty, for instance, urged local officials to view crimes that did not lead to personal gain more favourably, even suggesting granting complete freedom, leaving reduced sentences for 'selfish' crimes, including common crimes such as drunkenness and murder. The instructions implied that officials should err on the side of leniency if possible. ${ }^{75}$ Equally, the supreme tribunal was quick to intervene when it thought that amnesty should have been considered. The main military tribunal even circulated a note on 25 February 1921 complaining that too many military tribunals were pronouncing sentences 'without the right to amnesty', contradicting amnesty decrees and the sentiment behind them. ${ }^{76}$ All of the supreme tribunal's decisions went to the presidium of VTsIK for confirmation and were often changed again, usually reducing the sentence further.

Central authorities did not push through amnesties at any cost, however; rather, they insisted that regulations were adhered to and intervened accordingly, whether it led to a lesser or greater sentence. Tula's provincial tribunal, for example, illegally applied several amnesties simultaneously in November 1922 to repeatedly reduce sentences, as did Iaroslavl', who also lowered a sentence from one year to six months, before changing it illegally to a one million ruble fine due to the defendant's 'old age'. ${ }^{77}$ The supreme tribunal decreed that these sentences must be greater. VTsIK and Narkomiust also acted repeatedly to enforce correct procedure, whether reacting to appeals and chasing up cases, or spotting inconsistencies in the record. ${ }^{78}$ When Moscow tribunal reduced a sentence from five years to three years after the November 1920 amnesty, for instance, Narkomiust noted that the decree stipulated that sentences had to be reduced by two-thirds, a half or a third. It then suggested the sentence was reduced by two-thirds to one year eight months. ${ }^{79}$ 
Many interventions were prompted by appeals. Some appeals referred to particular points of an amnesty and related it to their case. Some were vaguer, noting that amnesties had benefited all types of criminals, implying that it was unfair that they had not been successful, or noted that those sentenced with them had benefited, but they had not. Some engaged with a perceived notion of the meaning of amnesty, claiming, for example, that an amnesty was an act of mercy and no-one can be denied mercy, or used the regime's own terminology, noting that no-one should be refused the right to atone for their crimes. Some reminded the regime of its supposed sympathy to workers and peasants caught up in a process that they did not deserve to be ${ }^{80}$ It is difficult to discover the outcome of specific appeals as information about cases can be scattered across archives, but it is clear that the most successful tactic was proving procedural error; a crime wrongly classified, a sentence incorrectly reduced, or a case not considered for amnesty when it should have been. Individuals were quick to appeal and equally quick to complain if the decision did not go their way. In 1921, for instance, 21 per cent of complaints (931) received by Narkomiust concerned accusations that amnesties and mercy had not been correctly applied, a number that equalled complaints against the Cheka and was only exceeded by complaints directed at people's courts. ${ }^{81}$

All of this demonstrates that amnesties were not intended to be purely for show. As the supreme tribunal reminded the Don regional tribunal, amnesties were created by the highest state organs and legal bodies could not refuse to implement them correctly. ${ }^{82} \mathrm{~A}$ similar message was conveyed to Saratov's provincial tribunal when it refused amnesty for two brothers on the grounds that they were 'enemies of the people'. Amnesties, the tribunal was told, were not concerned with whether defendants were 'enemies of the people' if their crimes were eligible under the terms decided by the state, as in this case. Saratov was ordered to review the case with a view to reducing the punishment. ${ }^{83}$ 
Overall, amnesties offered a good chance of reducing a sentence. General appeals could work, particularly if procedural error was proved, but levels of success declined over time. In last six months of $1918,47.6$ per cent of appeals led to the abolition of the original sentence, but this fell to 24 per cent in the first half of 1919 and 7.5 per cent in $1919-20 .^{84}$ Even then, most cases were retried and probably resentenced. It was possible to be considered for early release from late 1918 once half of a sentence had been served. Apparently, 67.4 per cent of those considered were released early in 1921 and a further 2.4 per cent had their sentences eased. ${ }^{85}$ There were also private acts of amnesty granted to individuals. In 1921, 81.5 per cent were rejected, 11.4 per cent released and 7.1 per cent had their sentence changed; in 1922, the figures were $64,18.6$ and 17.2 per cent respectively. ${ }^{86}$ But although becoming more successful, they were less common during the civil war than later.

The only route comparable in scale to amnesties was a rare official decree on a related matter. On 21 March 1921, the Council of People's Commissars (Sovnarkom) limited the maximum prison sentence to five years. ${ }^{87}$ This led to the reduction of thousands of sentences. The military college of the supreme tribunal was still rubber-stamping decisions in October to reduce the sentences of thousands of individuals convicted of crimes in military tribunals ranging from desertion, banditry, dereliction of duties and speculation, to forgery, agitation and drunkenness. Most had originally been sentenced to ten to twenty years. ${ }^{88}$

Indeed, Riazan's tribunal complained in April 1920 after being warned that it had not considered enough cases for amnesty that a false understanding of the state's mercy was leading all criminals to expect an amnesty. ${ }^{89}$ If true, this would have seriously undermined the value of amnesties to the state. As one scholar has noted, it must be impossible for criminals to count on amnesties for them not to undermine the seriousness of committing crimes. ${ }^{90}$ Riazan' may have been exaggerating, but defendants must have realised that frequent amnesties offered the quickest and easiest route to freedom during the civil war. 


\section{The Role of Amnesties}

Otto Kirchheimer argued that unlike individual acts of clemency, a wide-ranging amnesty 'must rest on a more coherent view of the desirable or necessary objectives'. ${ }^{91}$ If so, the Bolsheviks were never clear on these, assuming they existed. As noted, some elements of the amnesties were clear in their intentions, but broader motives remain obscure. The only overarching rationales championed by the Bolsheviks were mercy and circumstances, but if amnesties reflected the regime's 'humane' nature, then why did violence persist? There was admittedly a symbolic element at work here. Continuing to dispense harsh sentences for crimes whilst following them with acts of mercy left some prisoners with the impression that they had been released due to the state's humanity, even if they did not agree with the original sentence. ${ }^{92}$ Amnesties, then, projected an image of benevolence when little existed.

Equally, whilst many amnesties were clearly governed by circumstances - dealing with particular problems at pertinent times, linking in with other policies, or reflecting the changing fortunes of the Bolsheviks during the civil war - such language was not convincing in 1918-19 when the Bolsheviks were fighting desperately to survive. To be sure, there was also a symbolic element at work here as amnesties tried to portray an image of strength at a time when the state's existence was perilous.

Yet if amnesties were primarily about symbolism, one would expect them to be widely promoted. However, their publication was far more understated than it could have been. Most newspapers, such as Izvestiia and Pravda, published texts verbatim with few additional comments. ${ }^{93}$ The lack of comprehensive statistics, the absence of discussion in legal publications until after the civil war, and the silence in other accounts, all seem counterproductive if the purpose was to promote and celebrate. The Bolsheviks may have realized 
that greater publicity would ring false at a time when decrees urging merciless class war were being published, and amid arbitrary violence and growing authoritarianism.

Arguments situating amnesties within broader conceptions of crime and punishment are not convincing either, although, again, they contain elements of truth. In the transitional period before crime disappeared with the advent of socialism, crime was seen as the manifestation of the remnants of former practices and mentalities, of a primitive consciousness and of not just a criminal's personality but their socio-economic background. By viewing crimes as a 'social danger', moreover, it was easier to see the nature of any danger to society changing over time depending on circumstances. ${ }^{94}$ Amnesties, it was argued later, enabled the state to respond to the hundreds of people affected by dramatic changes wrought by events, mistakes made through a lack of consciousness, and the rapidly changing conditions of civil war that quickly rendered some former crimes harmless. But whereas the debates surrounding amnesty became more sophisticated in the mid 1920s, reflecting the growth of criminology more generally, ${ }^{95}$ such arguments do not appear to have been made publicly or privately - before 1922 . Furthermore, if amnesties meant that certain crimes were no longer considered socially dangerous, then why did the state continue to prosecute people for committing the same types of crimes?

Instead, Stuchka's revealing comment, noted above, in July 1918 that the Bolsheviks were interested in expediency not mercy suggests a significant part of the attraction of amnesties lay in their practical benefits, an attraction that also seemed to underpin the early initiatives of local authorities to introduce amnesties in the first half of 1918. Ultimately, the state was incapable of sustaining the high levels of coercion demanded by its decrees. Tribunals complained of understaffing, overwork and poor finances across this period. The same was true of other courts and institutions, including the Cheka, although little was done to alleviate these problems. In August 1920, Tula's provincial tribunal had half the amount of 
staff that it was supposed to have and this was not uncommon. ${ }^{96}$ When coupled with escalating unrest in 1920-2, tribunals faced immense pressures. A military tribunal in Tambov described working long days in June 1921 dealing with over 3,000 'bandits'. 97

Then there were numerous complaints throughout this period concerning inadequate prisons. In mid-late August 1918, Sovnarkom complained to the Commissariat for Internal Affairs (NKVD) that it was impossible to find places in Moscow's prisons; there were two to four people for every place, mentally-ill prisoners alongside others, numerous diseases and no-one transferred to hospital. Diseases had even spread to the surrounding urban population. None of this was acceptable. The NKVD's own report in early December confirmed all of this, as did a report for Moscow's provincial soviet. The latter noted that one solution might be to release more prisoners on bail, a suggestion that concurred with the state's later emphasis on suspended sentences. ${ }^{98}$ Similar scenarios existed elsewhere. In 1920, Piatigorsk prison held four times more prisoners than intended. Typhus, diphtheria and scurvy were flourishing and local attempts to deal with these problems were futile. ${ }^{99}$

Narkomiust's report to the Eighth All-Russian Congress of Soviets in late 1920 noted uncertainty over the exact number of prisoners and prison spaces nationally. By 1 October 1920 , there were 48,112 known prisoners in 42,083 places ( 1.14 people per place), but the report admitted that many prisons had three people per place. ${ }^{100} \mathrm{~A}$ year on, the report to the Ninth Congress painted a worse picture; 73,194 prisoners in 60,468 places (1.21 per place) and constant overcrowding. ${ }^{101}$ Most were held in a small number of severely overcrowded prisons in major cities. The Third All-Russian Congress of Representatives of Soviet Justice also noted that prisons only had 55 per cent of their quota of staff. There was even a lack of security; Nizhnii Novgorod's prison only had 78 per cent of the required number of guards. The congress concluded that the state lacked a coherent and realistic penal policy. ${ }^{102}$ 
Unsurprisingly, it was not suggested publicly that amnesties were intended to alleviate these problems, but it was indicated behind the scenes. Documents on the May 1920 amnesty are particularly revealing in this respect. A Narkomiust circular admitted that a basic aim was to transfer prisoners not in isolation to forced labour without imprisonment rather than complete freedom from punishment. ${ }^{103}$ Disseminating the circular, the main railway tribunal emphasized that the amnesty applied 'exclusively' to those sentenced to a fixed term of imprisonment and not to other types of sentences. The aim, again, was not to release people from all punishment, although this was possible in certain circumstances. ${ }^{104}$ Another circular instructed railway tribunals to target those with specialist knowledge, whether railways, military, economic, communications, or something else. ${ }^{105}$ This amnesty, then, was clearly seen as a means of alleviating pressures on prisons, whilst continuing to punish people (in a way that also provided income for the state) and, for some at least, as a means to release much-needed specialist workers.

Amnesties did make a difference to the justice system. The chairman of Tver's provincial tribunal noted that the November 1919 amnesty directly reduced workload, ${ }^{106}$ whilst a report to the First All-Russian Congress of Provincial Prison Departments in September 1920 highlighted that the November 1919 amnesty and the victories on some fronts of the civil war had combined to reduce the total prison population by 30 per cent. In terms of those serving sentences rather than awaiting trial, the impact was more dramatic with 75-80 per cent released in some places and 46 per cent across Russia. ${ }^{107}$ Equally, the monthly statistics on prison capacity in 1920-1 reveal that prisons were emptier in December-January and in June after the usual amnesties. ${ }^{108}$ Most prisoners were serving short sentences and amnesties were generous to such individuals. Around a third of sentences in people's courts involved imprisonment and 75 per cent were sentenced to less than a year, with 95 per cent to less than three years. ${ }^{109}$ Tribunals dispensed a higher percentage of custodial sentences, often 
three-quarters of all sentences, although declining rapidly during this period. A survey in 1919-20 revealed that almost 82 per cent of these sentences were less than five years. ${ }^{110}$ This fell to 36.6 per cent by the first half of 1921 , before Sovnarkom prohibited sentences over five years in March 1921. ${ }^{111}$

Any impact was short-lived, reducing the prison population for a couple of months before it increased again. Moreover, growing unrest led to more criminals. In 1920, the number of investigations by all courts was almost 11 per cent higher than in 1919 and the number of sentences was 81 per cent higher. Whilst the number of prisons fluctuated, it remained comparable (although spaces within each prison may have increased), and was no more than 12 per cent higher at best. ${ }^{112}$ This steady increase was repeated in 1921-2.

Thus whilst some western scholars have linked amnesties solely to the prison crisis, ${ }^{113}$ Fainblit denied that amnesties could be explained as a 'systematic' clearing of prisons (implying that such accusations had also been made by contemporaries). He did note that the immense task faced by punitive organs during the civil war made it 'tragically' inevitable that innocent workers and peasants would be caught up and amnesties were a periodic means of rectifying mistakes. However, he argued that the various amnesties lacked the continuity that would reflect a systematic penal policy and that this was because they reflected a more complex situation - the evolving political circumstances of the civil war years. ${ }^{114}$

Kirchheimer noted that amnesties help eradicate the "possibly disastrous consequences of a wrong political choice' and 'may contain a compromise, expressing the present relation of forces between the parties concerned'. ${ }^{115}$ Whilst the Bolsheviks were unswerving in their 'choice' to persecute rival political parties and made few 'compromises' to these parties, although individuals could be pardoned, a different picture emerges in the relationship with wider society. The civil war saw a determined effort to exert Bolshevik control over all 
aspects of life, and this created tensions and pressures. Relations with rural Russia were a particular problem as peasants came to dominate investigations.

Initially, most had committed crimes during their service in the Red Army or had deserted. One estimate suggested that 1.7 million people deserted from the army in $1919 .{ }^{116}$ This swamped courts, especially tribunals, with thousands of cases. As most fleeing soldiers were of peasant origin and returned to their villages, desertion was not confined to military tribunals. Provincial tribunals established special departments and organized mobile tribunals to visit villages. Yet despite their unreliability, deserters were needed to maintain the fighting strength of the army and amnesties formed part of an evolving policy of incentives and punishments designed to combat the problem. One contemporary later argued that amnesties could have a significant impact as long as they were introduced when deserters were receptive, were not too frequent, and were applied alongside repression. ${ }^{117}$ Entire 'amnesty weeks' were offered in 1919. The most successful was 3-9 June, when 98,183 deserters returned, and it was extended for a month, raising the total to $436,398 .^{118}$

Increasingly, peasants were also prosecuted for resisting the state's food seizures and exceptional taxes, especially when alternatives to Bolshevik rule appeared in the form of the 'Green' movement in 1920-1. Tribunals faced sentencing thousands of peasants involved in 'banditry' or armed resistance. Entire villages were implicated and even if it was possible to incarcerate entire villages it would neither solve the economic problems nor the unrest. Equally, as a circular from the Cheka on 17 April 1920 to all its provincial branches advised, severe repression lost its impact when used constantly and thus should be reserved for the most harmful elements. ${ }^{119}$ Amnesties provided an alternative approach and helped relieve this pressure without publicly undermining Bolshevik principles. One observer implied that a special amnesty directed at entire units of the Antonov revolt in Tambov enjoyed some success. ${ }^{120}$ The leading historian of the revolt also noted varying degrees of success across 
districts and the involvement of thousands of peasants, although he argued that amnesties had little impact on the bigger picture. For an amnesty to work, peasant rebels had to know about it, desire it and trust the Bolsheviks to honour it, all of which was doubtful. ${ }^{121}$ This is true, but there was a difference between a revolt's leaders and its foot soldiers. As has been noted in the Ukraine, most peasants became 'bandits' because they were forcibly mobilized by local leaders, attempting to avoid conscription into the army, or were reacting to (or seeking revenge for) seizures of food and property. Most soon tired of fighting, feared for their family and homes, and were attracted by the offer of an amnesty, especially after rural policies eased in 1921. Even those who enjoyed banditry were convinced that the tide was turning against them in 1921 and amnesties provided an exit. ${ }^{122}$

Finally, as the civil war ended, amnesties aided reconciliation. Amnesties were used to target areas of the country deeply affected by the war, an obvious example being the Crimea in May 1921 where the crude characterization of the ethnic Tatar population as 'backward' served to absolve them from blame for resistance. ${ }^{123}$ The supreme tribunal tried to restrict death sentences among tribunals from 1920 onwards to relieve internal dissent, a tactic that became even more pronounced after the November 1922 amnesty. ${ }^{124}$ In October 1922, the chairman of VTsIK, M. I. Kalinin, during a visit to Nizhnii Novgorod, sanctioned the release of several hundred peasants and workers convicted of petty crimes who promised to become productive members of society. A fortnight later, his representative wrote to a people's court in the province asking whether it could change a sentence in a specific case from a fine to imprisonment so that the case would fall under the November 1922 amnesty and allow the defendant to be freed. Such actions, it was insinuated, should be more common. ${ }^{125}$

Amnesties, therefore, were an invaluable tool in the dangerous balancing act being attempted by the state. Early release in any form could undermine the punitive policies of the state and legal sentences in particular, ${ }^{126}$ and the state could not allow its punitive system to 
be seen as lacking substance. Yet it did lack substance in many ways and the state was forced to respond to these weaknesses. As long as the state was convinced that those convicted did not come to expect an amnesty as claimed by Riazan' - and it does seem to have remained oblivious to this possibility - amnesties offered an ideologically acceptable way out. They relieved crucial pressures on the justice system, and tensions between the state and particular social groups, whilst maintaining the state's basic position that certain activities were crimes and deserved a harsh punishment. Moreover, they did so in way that could not only be fitted into prevailing views on crime and punishment but, more importantly, portrayed the state in a merciful and humane manner. Thus despite the act and the harmful nature of that act, which was always stressed, there would be no further consequences, and this was solely down to the benevolence of the state.

\section{$\underline{\text { Conclusion }}$}

A study of amnesties in the late 1920s declared confidently that the November 1918 amnesty was a 'historic' document. ${ }^{127}$ Such a claim seems overblown as this was not the first Russian amnesty or even soviet amnesty. It was, though, the first officially-sanctioned soviet amnesty and established amnesties as a feature of the civil war. These amnesties were not a sign of mercy or humanity on the part of the Bolsheviks; they never admitted mistakes or granted innocence, but excused, underplayed or misrepresented crimes and their significance. The state was interested in expediency not mercy, and amnesties had a range of practical functions, not least of which was to act as a 'safety valve' to release burgeoning pressures on the fledgling justice system and tensions between state and society.

One scholar has noted that just as criminals must not be able to count on amnesties if the justice system is to remain effective, so too must an amnesty's goals remain clear, and its 
use restricted and carefully managed, if amnesty is not to represent the intrusion of politics into law. ${ }^{128}$ Such conditions were not met during the civil war; amnesties were frequent and their broad goals unclear, whilst specific parts of particular amnesties clearly did have political objectives. The sheer frequency of amnesties, moreover, suggests that they became seen by the Bolsheviks as a means to achieve political goals much in the same way as violence became a tool that could be readily employed to further state objectives. ${ }^{129}$

These practical functions ensured that amnesties persisted after the civil war. In the 1920s, they aided reconciliation with those who had fought for the White movement, if not its leaders, ${ }^{130}$ whilst the amnesty commemorating the revolution's ten year anniversary reduced the prison population from 126,270 to 82,409 by early $1928 .{ }^{131}$ They played a role in Stalin's Russia and afterwards, with major amnesties in 1945 and 1953 in particular, both of which were promoted as examples of soviet 'humanity'. ${ }^{132}$ And amnesties continue to play a role in post-Soviet Russia. ${ }^{133}$ There has been much debate recently about the political objectives of the economic amnesty in July 2013 and the amnesty in December 2013 to celebrate the twentieth anniversary of the constitution. ${ }^{134}$

At the very least, civil war amnesties should force us to paint a more complex picture of repression, justice and power in the early soviet state. Amnesties reflected the weakness of the state's fledgling repressive organs, which were unable to cope with the scale of the unrest prompted by civil war. Violence could not be the sole solution to internal opposition, and the continued emphasis placed centrally and locally on the justice system demonstrated the state's recognition that it was not a case of justice or terror, but a judicious combination of the two. Amnesties may have been forced upon the state in certain respects, but at the same time, their development over the civil war also reflected the slow expansion of central state power. From steadily exerting control over amnesties in 1918 to enforcing instructions on interpreting amnesties and supervising local courts, central state organs took control over the timing and 
implementation of amnesties. The history of amnesties during the civil war, therefore, is broadly a history of the reassertion of central authority as the turbulence of revolution started to come to an end.

The majority of the research for this article was funded by a research fellowship from The Leverhulme Trust and I am very grateful for their support. Additional research emerged from a related project funded by the British Academy to whom I am also very grateful. As well as the anonymous reviewers, I would like to thank the following for their comments and help on various aspects of this research: Murray Frame, Chris Gilley, Daniel Newman, Aaron Retish, James Ryan, Alistair Wright, and the Study Group on the Russian Revolution.

${ }^{1}$ M. Jakobson, Origins of the Gulag: The Soviet Prison Camp System, 1917-1934 (hereafter Origins), Lexington, KY, 1993, p. 20.

${ }^{2}$ M. Freeman, Necessary Evils: Amnesties and the Search for Justice, Cambridge, 2009, pp. $12-17$.

${ }^{3}$ For e.g., N. Popov, ‘Amnistiia v oznamenovanie obrazovaniia SSSR osnovnye zadachi organov sovetskoi iustitsii v bor'be s prestupnost'iu', Ezhenedel'nik sovetskoi iustitsii, 13 September 1923, 36, pp. 817-19.

${ }^{4}$ S Fainblit, Amnistiia i sudebnyi prigovor (hereafter Amnistiia), Moscow-Leningrad, 1927, pp. 3-7.

${ }^{5}$ B. Utevskii, Dosrochnoe osvobozhdenie i amnistiia (hereafter Dosrochnoe), Moscow, 1927, pp. 3-4. 
${ }^{6}$ On amnesties, see N. Durmanov, Ozvobozhdenie ot nakazaniia po Sovetskomu pravu (hereafter Ozvobozhdenie), Moscow, 1957; P. Romashkin, Amnistiia i pomilovanie v SSSR (hereafter Amnistiia), Moscow, 1959; and V. Kvashis, Gumanizm sovetskogo ugolovnogo prava, Moscow, 1969. For a range of legal histories, see N. Krylenko, Sudoustroistvo RSFSR, Moscow, 1923; M. Kozhevnikov, Istoriia sovetskogo suda 1917-1956 gody (hereafter Istoriia), Moscow, 1957; and V. Portnov and M. Slavin, Stanovlenie pravosudiia Sovetskoi Rossii (1917-1922 gg.), Moscow, 1990. The only known post-Soviet study of civil war amnesties focuses on the Ukraine; V. Vasilenko, 'Bil'shovits'ki amnistii pochatku 1920-x rr. iak zasib borot'bi proti povstans'kogo rukhu' (hereafter 'Bil'shovits'ki'), $\underline{Z}$ arkhiviv VUChKGPU-NKVD-KGB, 2011, 1, pp. 89-155, available at <www.history.org.ua/?litera\&id=7270> [accessed 31 March 2014] (I am very grateful to Chris Gilley for this reference).

${ }^{7}$ G. Alexopoulos, Soviet Amnesty Tales: Stories of Redemption, 1920s-1960s (hereafter Amnesty Tales), Washington, DC, 2004, pp. 1-2; J. Hazard, Settling Disputes in Soviet Society, New York, 1960, pp. 81-2; P. Solomon, ‘Soviet Penal Policy, 1917-1934: A Reinterpretation', Slavic Review, 39, 1980, 2, pp. 195-217 (p. 199); and idem, $\underline{\text { Soviet }}$ Criminal Justice under Stalin, Cambridge, 1996, pp. 67-8, 421-2, 441-2. The incomplete prison system was also emphasized in VChK-GPU. Dokumenty i materialy, ed. Iu. Fel'shtinskii, Moscow, 1995, p. 12.

${ }^{8}$ I borrow this term from B. McKnight, The Quality of Mercy: Amnesties and Traditional Chinese Justice, Honolulu, HI, 1981, p. 117, who argues that amnesties played a similar role in medieval and early modern China.

${ }^{9}$ Studies of tribunals also say little on amnesties; see Iu. Titov's three-volume study:

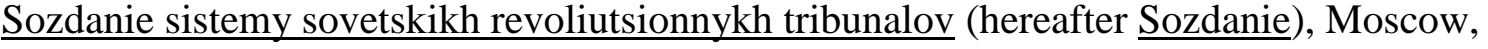
1983; Razvitie sistemy sovetskikh revoliutsionnykh tribunalov, Moscow, 1987; and 
Sovetskie revoliutsionnye tribunaly v mirnye gody stroitel'stva sotsializma, Moscow, 1988; and N. Smirnov, Vysshie sudy revoliutsii (Tsentral'nye revoliutsionnye tribunaly, 19181922gg.), Moscow, 1990. There have been a number of recent dissertations on tribunals, but only a few briefly mention amnesties; see V. Abramov, 'Sozdanie i deiatel'nost' mestnykh revoliutsionnykh tribunalov (1918-1922 gg.) (po materialam Penzenskoi gubernii)', unpublished kandidat dissertation, Penza State Pedagogical University, 2004, pp. 137-41; P. Fedorenko, 'Revoliutsionnye tribunaly Smolenskoi gubernii (dekabr’ 1917-1922 gg.)’, unpublished kandidat dissertation, Smolensk State University, 2006, pp. 103-06; and C. Story, 'In a Court of Law: The Revolutionary Tribunals in the Russian Civil War, 1917-1921' (hereafter 'Court'), unpublished PhD dissertation, University of California Santa Cruz, 1998, pp. 123-7.

${ }^{10}$ H. Dewey and A. Kleimola, 'Old Muscovite Amnesties: Theory and Practice', $\underline{\text { Russian }}$ History, 3, 1976, 1, pp. 49-60.

${ }^{11}$ J. Burbank, 'Mercy, Punishment, and Law: The Qualities of Justice at Township Courts', Kritika, 7, 2006, 1, pp. 23-60; R. Wortman, Scenarios of Power: Myth and Ceremony in Russian Monarchy, 2 vols, Princeton, NJ, 1995-2000, I, pp. 457-8.

${ }^{12}$ The Russian Provisional Government 1917, eds. R. Browder and A. Kerensky, 3 vols, Stanford, CA, 1961, I, pp. 196-8.

${ }^{13}$ Gosudarstvennyi arkhiv Rossiiskoi Federatsii (hereafter GARF), f. A-353 (Narodnyi komissariat iustitsii RSFSR), op. 2, d. 207, 11. 1-11 (various correspondence, March-June 1918).

14 'Kratkaia zapiska o sudakh revoliutsionnogo vremeni v Timskom uezde', Materialy

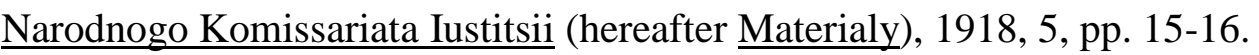

${ }^{15}$ Jakobson, Origins, p. 29. 
${ }^{16}$ A. Rabinowitch, The Bolsheviks in Power, Bloomington and Indianapolis, IN, 2007, pp. 221-2.

${ }^{17}$ Izvestiia, 1 May 1918, p. 5; Vpered!, 1 May 1918, p. 3.

${ }^{18}$ Izvestiia, 3 May 1918, p. 3.

${ }^{19}$ GARF, f. A-353, op. 2, d. 2, 1.38 (protocols of the meetings of the college, 10 May 1918).

${ }^{20}$ GARF, f. A-353, op. 2, d. 2, 1.42 (protocols, 14 May 1918).

${ }^{21}$ Vpered!, 3 May 1918, p. 3; 4 May 1918, p. 2.

${ }^{22}$ GARF, f. R-336 (Sledstvennaia komissiia revoliutsionnogo tribunala pri Petrogradskom sovete rabochikh, krest'ianskikh i soldatskikh deputatov), op. 1, d. 334, 11.9 (appeal for A. D. Khomutov, 22 May 1918), 11 (resolution of the investigative commission, 27 May 1918).

${ }^{23}$ GARF, f. R-336, op. 1, d. 73, 1. 1ob; d. 75, 1.1 (pre-printed forms).

${ }^{24}$ Vpered!, 4 May 1918, p. 3.

${ }^{25}$ See, for e.g., newspapers from Samara and Shuia; Za svobodu!, 30 April 1918, p. 2;

Izvestiia Shuiskago soveta, 1 May 1918, p. 3.

${ }^{26}$ GARF, f. A-353, op. 2, d. 27, 11. 55ob-56 (report of Penza's provincial commissar of justice to a congress of local commissars of justice in Moscow, 28 June 1918).

27 Titov, Sozdanie, pp. 35-6.

${ }^{28}$ GARF, f. A-353, op. 2, d. 2, 1. 61 (protocols, 6 June 1918).

29 'Zhurnal soedinennogo zasedaniia sektsii Vtorogo Vserossiiskogo S”ezda Oblastnykh i

Gubernskikh Komissarov Iustitsii. 4-go Iiulia 1918 g.', Materialy, 1918, 3, pp. 33-4.

${ }^{30}$ Romashkin, Amnistiia, p. 80.

${ }^{31}$ Shestoi vserossiiskii chrezvychainyi s"ezd sovetov rab., kr., kaz. i krasnoarm. deput.

Stenograficheskii otchet. 6-9 noiabria 1918 g. (hereafter Shestoi), Moscow, 1919, pp. 37-8. Also O. Zalogina, 'Voprosy gosudarstva i prava v resheniiakh VI Vserossiiskogo 
chrezvychainogo s"ezda sovetov' in Iz istorii sovetskogo gosudarstva i prava, Moscow, 1989, pp. 36-45.

${ }^{32}$ The decree is reprinted in Romashkin, Amnistiia, pp. 82-3; and Dekrety sovetskoi vlasti (hereafter Dekrety), 18 vols, Moscow, 1957-2009, III, pp. 529-30. Henceforth, the texts are cited from Romashkin. See also Izvestiia, 9 November 1918, p. 2; and Pravda, 9 November 1917, p. 3. It is not clear who wrote it. In 1920-2, Narkomiust wrote amnesties, passing them to VTsIK for confirmation, but I have not found comparable records for 1918-19; GARF, f. A-353, op. 4, d. 444, 1. 136 (protocols, 4 November 1920); op. 6, d. 66, 11. 128-29 (protocols, 13 and 20 October 1922).

${ }^{33}$ Shestoi, p. 38.

${ }^{34}$ Arkhiv VChK: Sbornik dokumentov (hereafter Arkhiv VChK), Moscow, 2007, p. 295 (Cheka presidium meeting, 15 November 1918).

${ }^{35}$ Arkhiv VChK, p. 295 (Cheka presidium meeting); Iz istorii Vserossiiskoi chrezvychainoi komissii (1917-1921 gg.), Moscow, 1958, p. 217 (VTsIK presidium meeting, 18 November 1918).

${ }^{36}$ Izvestiia, 23 February 1919, p. 3.

${ }^{37}$ Romashkin, Amnistiia, p. 83. In this case, the version in Dekrety (V, pp. 153-4) is different, but the gist is the same.

${ }^{38}$ Romashkin, Amnistiia, pp. 84-6.

${ }^{39}$ Romashkin, Amnistiia, p. 302. Instructions were later published in national newspapers; for e.g. Pravda, 6 November 1920, p. 8; and 9 November 1922, p. 5.

${ }^{40}$ GARF, f. A-353, op. 4, dd. 45-46 contains hundreds of queries relating to the November 1921 and 1920 amnesties respectively. Numerous other dela hold many more additional queries for all amnesties. 
${ }^{41}$ GARF, f. R-3042 (Voenno-transportnaia kollegiia verkhovnogo suda RSFSR), op. 1, d. 2, 11. 10-11 (circular to railway tribunals, November 1920); Tsentral'nyi gosudarstvennyi arkhiv Moskovskoi oblasti (hereafter TsGAMO), f. 4762 (Moskovskii okruzhnoi voennotransportnyi tribunal), op. 1, d. 1, 11. 45, 49-49ob (orders to local tribunals, 24 November and 29 November 1922).

${ }^{42}$ Amnistiia 1922 goda k V-i godovshchine Oktiabr'skoi revoliutsii (hereafter Amnistiia 1922), Moscow, 1922.

${ }^{43}$ There were general amnesties on 1 May 1920, 6 November 1920, 29 April 1921, 3-4 November 1921, 27 February 1922 and 2 November 1922, as well as several specific ones; Romashkin, Amnistiia, pp. 86-100, 302-21.

${ }^{44}$ Peace treaties also provided amnesties for Estonians, Finns, Latvians, Lithuanians and Poles imprisoned in Russia for political crimes. On 10 February 1921, an inter-departmental committee with provincial branches was created to implement them: GARF, f. R-5209 (Mezhduvedomstvennaia komissiia po provedeniiu amnistii soglasno mezhdunarodnym dogovoram, zakliuchennym RSFSR), op. 1, d. 1, 1. 202 (report of the chair of the committee to the presidium of the Cheka, 19 April 1921) and other documents in the delo. ${ }^{45}$ A newspaper in Odessa argued that an amnesty for those who fought with the Ukrainian leader, S. V. Petliura, against the Bolsheviks would reconcile past local conflict; Pravda, 5 June 1921, p. 1. Such an amnesty was part of the decree on 3 November and was later extended by the Ukrainian authorities; C. Gilley, The 'Change of Signposts' in the Ukrainian Emigration, Stuttgart, 2009, pp. 232-42.

${ }^{46}$ Amnistiia 1922, pp. 9, 17-18.

${ }^{47}$ Romashkin's volume contains amnesty texts from various republics; Amnistiia, pp. 137-54, 274-88, 302-17. 
${ }^{48}$ GARF, f. R-1005 (Verkhovnyi tribunal pri VTsIK), op. 1, d. 85, 1. 282 (excerpt from Izvestiia Narkomvnudela Sotsialisticheskoi Sovetskoi Respubliki Gruzii, 23 April 1921). ${ }^{49}$ See Vasilenko, 'Bil'shovits'ki'.

${ }^{50}$ Romashkin, Amnistiia, p. 90; Izvestiia, 9 November 1920, p. 3; Pravda, 9 November 1920, p. 2. VTsIK also approved an amnesty declared in the Mountain (Gorskaia) Republic (now Ingushetiia) on 1 May 1921, although one senses that it had little choice: GARF, f. R-1005, op. 1, d. 5, 1. 27 (protocol of VTsIK meeting, 15 June 1921).

${ }^{51}$ GARF, f. R-1005, op. 3, d. 1, 1l. 78 (meeting of the supreme tribunal's plenum, 19 November 1921), 79-83 (telegram to VTsIK, 14 November 1921), 88-89ob (regulations on amnesties in republics and regions, undated).

${ }^{52}$ GARF, f. A-353, op. 4, d. 30, 11. 1-2 (correspondence, June 1920).

${ }^{53}$ GARF, f. R-1005, op. 1, d. 86, 11. 421-3 (correspondence, March 1921).

${ }^{54}$ TsGAMO, f. 4998 (Otdel iustitsii Mossoveta), op. 1, d. 13, 1. 44ob (protocol of meeting). ${ }^{55}$ TsGAMO, f. 66 (Moskovskii sovet), op. 25, d. 8, 11. 8-40 (protocols of Moscow tribunal, 13-29 November 1918). Seventy-six people are noted in the records plus an unspecified number of factory 'officials'. These numbers differ from those in Story, 'Court', pp. 123-7, 141.

${ }^{56}$ GARF, f. A-353, op. 2, d. 78b, 11. 189-89ob (report of Tula's department of justice to Narkomiust, 29 November 1919).

${ }^{57}$ See the reports on amnesty commissions in Smolensk after November 1920 (GARF, f. A353, op. 4, d. 46, 1. 490), and after November 1921, Omsk (op. 5, d. 17, 1. 72ob) and Orel (op. 4, d. $45,1.14)$. 
${ }^{58}$ GARF, f. R-1005, op. 2, d. 63, 11. 47-47ob (circular from Tula's department of justice to local organs, 13 May 1920); op. 3, d. 137, 1. 25 (circular from Kursk's tribunal to all local mobile tribunals, 26 November 1921).

${ }^{59}$ One scholar faced the same problem recently when trying to assess the impact of amnesties in the Ukraine; Vasilenko, 'Bil'shovits'ki', pp. 91-2.

${ }^{60}$ Reports to Narkomiust; GARF, f. A-353, op. 3, d. 211, 11. 2 (Perm', 23 December 1919), 710 (Riazan', 31 December 1919), 17 (Tver', 9 January 1920), 57 (Ekaterinburg, 31 January 1920), 58 (Kazan', undated), 77 (Orel and Briansk, undated).

${ }^{61}$ GARF, f. R-1005, op. 3, d. 38, 1.19 (report on Perm's tribunal in 1919-20 to the provincial executive committee, 14 January 1921).

${ }^{62}$ GARF, f. R-1005, op. 3, d. 10, 1. 25 (report on Arkhagel'sk's tribunal in January to November 1921, 23 November 1921).

${ }^{63}$ One contemporary claimed that the Cheka preferred to execute people on the eve of an amnesty rather than release them (S. Melgounov, The Red Terror in Russia, Westport, CT, 1975, p. 54), but other evidence suggests that the Cheka also released hundreds either being investigated or already incarcerated for petty crimes; see, for e.g, a report in Krasnaia gazeta, 12 November 1919 , p. 2.

${ }^{64}$ GARF, f. R-1005, op. 1, d. 73, 11. 230-30ob (list of prisoners).

${ }^{65}$ GARF, f. R-1005, op. 1a, d. 511, 11. 18-21, 24, 31-31ob (various appeals and resolutions, 1922). These officials were themselves amnestied in November 1922.

${ }^{66}$ GARF, f. A-353, op. 4, d. 111, 1.210 (report on military tribunals in the first half of 1920, undated).

${ }^{67}$ For e.g., the case of A. N. Nikolaev; GARF, f. R-1005, op. 1a, d. 28, 11. 64-74 (various documents, 1919-20). 
${ }^{68}$ For e.g., the case of E. G. Voloskov; GARF, f. R-1005, op. 7, d. 560, 1.9 (resolution of VTsIK's regulation committee, 20 January 1921).

${ }^{69}$ TsGAMO, f. 4762, op. 1, d. 14, 1.36 (sentence).

${ }^{70}$ GARF, f. R-1005, op. 7, d. 85, 1. 5ob.

${ }^{71}$ GARF, f. R-1005, op. 2, d. 21, 11. 122-22ob (case report from the secretary of the tribunal).

${ }^{72}$ GARF, f. R-1235 (VTsIK), op. 56, d. 13, 1.37 (resolution of Novgorod's tribunal, 8 May 1920).

${ }^{73}$ GARF, f. R-1005, op. 1, d. 25, 1.100 (telegram to the military college of VTsIK).

${ }^{74}$ GARF, f. R-1005, op. 1, d. 59, 11. 73-73ob (report).

${ }^{75}$ GARF, f. R-1005, op. 1, d. 44, 11. 7-7ob (circular from the main military tribunal to all military tribunals, 13 January 1921).

${ }^{76}$ GARF, f. R-1005, op. 1, d. 44, 1.59 (circular from the main military tribunal to all military tribunals).

${ }^{77}$ GARF, f. R-1005, op. 3, d. 194, 11. 121-21ob (supreme tribunal to the chairman of Tula's tribunal, 2 November 1922); d. 205, 1.3 (report on Iaroslavl''s tribunal from an inspection on 12-14 February 1922).

${ }^{78}$ See, for e.g., VTsIK's correspondence on amnesties in GARF, f. 1235, op. 56, d. 16.

${ }^{79}$ GARF, f. A-353, op. 5, d. 355, 11. 42-43 (correspondence, April 1921).

${ }^{80}$ For appeals utilizing these approaches, see GARF, f. R-1005, op. 1a, d. 28, 1. 69; op. 1a, d. 1409, 11. 195, 225ob; op. 2, d. 20, 11. 251-51ob; op. 2, d. 1, 11. 398-98ob; op. 7, d. 125, 1. 2 ob.

81 RSFSR. Narodnyi Komissariat Iustitsii. Otchet IX Vserossiiskomu s"ezdu sovetov, Moscow, 1921, p. 9.

${ }^{82}$ GARF, f. R-1005, op. 3, d. 206, 11. 175-75ob (correspondence, December 1922).

${ }^{83}$ GARF, f. R-1005, op. 7, d. 700, 1.2 (resolution on the appeal from 13 July 1920, undated). 
${ }^{84}$ GARF, f. R-1005, op. 2, d. 3, 11. 142-143 (reports from the cassation tribunal of VTsIK, undated); d. 1, 1. 284ob (report of the cassation tribunal on 1919-20 to the Eighth All-Russian Congress of Soviets, undated).

${ }^{85}$ V. Iakubson, 'Dosrochnoe osvobozhdenie v RSFSR za 1921 godu', Ezhenedel'nik sovetskoi iustitsii, 30 December 1922, 46-7, pp. 7-10. See also Durmanov, Ozvobozhdenie, p. 43; and Utevskii, Dosrochnoe, pp. 3-40.

${ }^{86}$ Fainblit, Amnistiia, p. 32.

${ }^{87}$ Reprinted in Istoriia zakonodatel'stva SSSR i RSFSR po ugolovnomu protsessu i organizatsii suda i prokuratury, 1917-1954, Moscow, 1955, p. 165.

${ }^{88}$ See the numerous lists in GARF, f. R-1005, op. 1, dd. 73-74. Some contain over 2,000 names.

${ }^{89}$ GARF, f. R-1005, op. 2, d. 2, 1.290 (Riazan’’s tribunal to VTsIK, 18 April 1920).

${ }^{90}$ P. Krapp, 'Amnesty: Between an Ethics of Forgiveness and the Politics of Forgetting' [hereafter Amnesty], German Law Journal, 6, 2005, 1, pp. 185-95 (p. 193).

${ }^{91}$ O. Kirchheimer, Political Justice: The Use of Legal Procedure for Political Ends (hereafter Political Justice), Princeton, NJ, 1961, p. 405.

${ }^{92}$ Vasilenko argued that the Ukrainian authorities deliberately dispensed excessive sentences for minor crimes in order to reduce them and demonstrate humanity and generosity; 'Bil'shovits'ki', p. 112.

${ }^{93}$ Research in various national and local newspapers has produced only a few exceptions. These tended to note how amnesties reflected favourably on the new state; see Krasnoe $\underline{\text { znamia }}$ [Penza], 7 November 1919, p. 1 and 9 November 1920, p. 1; $\underline{\text { Krasnaia gazeta }}$ [Petrograd], 9 November 1919, p. 4; and 슬 [Orsha], 15 November 1919, p. 1. Krasnoe 
znamia also published lists of over 250 individuals freed by the November 1919 amnesty, no doubt as a means of promoting it (see 18-21, 25-26 November 1919).

${ }^{94}$ On these ideas after 1917, see S. Kowalsky, Deviant Women: Female Crime and Criminality in Revolutionary Russia, 1880-1930, DeKalb, IL, 2009, pp. 9, 60-5; and D. Beer, Renovating Russia: The Human Sciences and the Fate of Liberal Modernity, 1880-1930, Ithaca, NY, 2008, pp. 194-5.

${ }^{95}$ See L. Shelley, 'Soviet Criminology: Its Birth and Demise, 1917-1936', Slavic Review, 38, 1979, 4, pp. 614-28.

${ }^{96}$ GARF, f. R-1005, op. 2, d. 63, 1.2 (report of Tula's tribunal to its executive committee, 6 August 1920).

${ }^{97}$ GARF, f. R-1005, op. 1, d. 51, 1.63 (report of Tambov's military tribunal to the main military tribunal, 12 June 1921).

${ }^{98}$ GARF, f. R-393 (Narodnyi komissariat vnutrennikh del), op. 1, d. 29, 1.69 (Sovnarkom to the NKVD, undated); op. 3, d. 510, 11. 353-353ob, 356 (NKVD report on prisons, undated); op. 3, d. 216, 1. 196ob (protocol of an emergency meeting of Moscow's provincial executive committee, 11 December 1918).

${ }^{99}$ GARF, f. R-1005, op. 2, d. 56a, 1. 63 (report of Piatigorsk's tribunal to the cassation tribunal, 25 September 1920).

100 ‘Tiuremnoe delo v 1920 godu' (hereafter 'Tiuremnoe delo'), Materialy, 1920, 8, pp. 11920 (report by the Commissar of Justice to the Eighth All-Russian congress of Soviets). Three organs (Narkomiust, NKVD and the Cheka) oversaw prisoners during this period, sometimes in the same prison. These numbers are for Narkomiust prisons, but similar numbers existed in NKVD prisons; Jakobson, Origins, p. 24. 
${ }^{101}$ RSFSR. Tiuremnoe delo v 1921 godu. Otchet Narodnogo Komissariata Iustitsii po

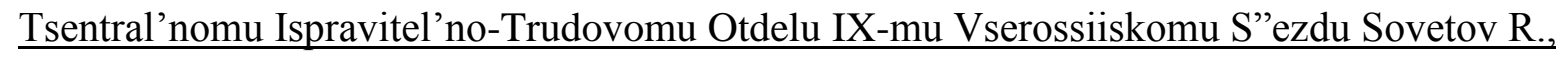
Kr., i K. D., Moscow, 1921, p. 8.

102 Materialy, 1921, 11-12, pp. 47, 59 (minutes, 25-29 June 1920).

${ }^{103}$ GARF, f. R-3042, op. 1, d. 15, 1.11 (instructions, undated). Forced labour without imprisonment (a type of community service) and paying a portion (25-50 per cent) of wages earned to the authorities had been encouraged by Narkomiust since 1918 . There is no evidence on whether it could be enforced effectively.

${ }^{104}$ GARF, f. R-3042, op. 1, d. 15, 11. 13-13ob (instructions, 8 May 1920).

${ }^{105}$ GARF, f. R-3042, op. 1, d. 2, 1. 13ob (telegram, 6 May 1920).

${ }^{106}$ GARF, f. R-1005, op. 2, d. 61, 1.22 (report to the cassation tribunal, 3 January 1920).

107 ‘Doklad po Administrativno-Raspredelitel'nomu Otdelu TsKO' (hereafter 'Doklad'), Materialy, 1920, 8, p. 30.

108 'Tiuremnoe delo', 120.

${ }^{109}$ E. Tarnovskii, ‘Sudebnaia repressiia v tsifrakh za 1919-1922gg.', Ezhenedel'nik sovetskoi iustitsii, 7 December 1922, 44-45, pp. 43-4.

${ }^{110}$ Kozhevnikov, Istoriia, p. 86.

${ }^{111}$ D. Rodin, 'Revoliutsionnye tribunaly v 1920-1922 gg.', Vestnik statistiki, 8, 1923, 1-3, pp. 155-89 (p. 168).

112 'Doklad', pp. 31-3.

${ }^{113}$ Most obviously, P. Juviler, Revolutionary Law and Order: Politics and Social Change in the USSR, New York, 1976, pp. 34-5, but also the works by Solomon cited earlier.

${ }^{114}$ Fainblit, Amnistiia, pp. 17, 36-7.

${ }^{115}$ Kirchheimer, Political Justice, p. 410. 
${ }^{116}$ S. Olikov, Dezertirstvo v Krasnoi armii i bor'ba s nim (hereafter Dezertirstvo), Moscow, 1926, pp. 30-1.

${ }^{117}$ Olikov, Dezertirstvo, p. 51. See also J. Sanborn, Drafting the Russian Nation, DeKalb, IL, 2003, pp. 50-5; and A. Wright, 'Stemming the Flow: The Red Army Anti-Desertion

Campaign in Soviet Karelia (1919)', Revolutionary Russia, 25, 2012, 2, pp. 141-62 (pp. 154-

$5)$.

${ }^{118}$ Olikov, Dezertirstvo, pp. 40-42, 100-02.

${ }^{119}$ GARF, f. R-1005, op. 1, d. 76, 1. 361ob.

${ }^{120}$ D. Smirnov, Zapiski chekista, $2^{\text {nd }}$ edition, Minsk, 1972, p. 73.

${ }^{121}$ E. Landis, Bandits and Partisans: The Antonov Movement in the Russian Civil War,

Pittsburgh, PA, 2008, pp. 111-12, 208-09, 256, 343.

${ }^{122}$ Vasilenko, 'Bil'shovits'ki', pp. 102, 109-11.

${ }^{123}$ GARF, f. R-1005, op. 1, d. 49, 11. 151-51ob (order of the Crimean Revolutionary

Committee, 3 May 1921).

${ }^{124}$ According to a circular to railway tribunals, a basic point of the November 1920 amnesty was to try to ease death sentences; GARF, f. R-3042, op. 1, d. 15, 1. 49 (6 November 1920). ${ }^{125}$ GARF, f. R-1235, op. 58, d. 18, 11. 190-1, 281 (correspondence, 27 October 1922 and 13 November 1922).

${ }^{126}$ As was recognized by contemporaries; Utevskii, Dosrochnoe, pp. 6-7.

${ }^{127}$ Fainblit, Amnistiia, p. 7.

${ }^{128}$ Krapp, ‘Amnesty’, p. 193.

${ }^{129}$ See P. Holquist, 'State Violence as Technique: The Logic of Violence in Soviet

Totalitarianism', in A. Weiner (ed.), Landscaping the Human Garden, Stanford, CA, 2003, pp. 19-45. 
${ }^{130}$ N. Ablazhei and E. Komissarova, 'Amnistiia riadovykh belogvardeitsev i ikh reemigratsiia iz Kitaia v 1920-e gg.', Gumanitarnye nauki v Sibiri, 2007, 2, pp. 49-52.

${ }^{131}$ A. G., 'Itogi amnistii v oznamenovanie desiatiletiia oktiabr'skoi revoliutsii', $\underline{\text { Revoliutsiia }}$ prava, 1929, 1, pp. 112-15 (p. 113). See also A. Trainin, Amnistiia k desiatoi godovshchine, Moscow, 1927; and Statistika amnistirovannykh v oznamenovanie desiatiletiia oktiabr'skoi revoliutsii, Moscow, 1928.

${ }^{132}$ Alexopoulos, Amnesty Tales; G. Alexopoulos, 'Amnesty 1945: The Revolving Door of Stalin's Gulag', Slavic Review, 64, 2005, 2, pp. 274-306; M. Dobson, “"Show the BanditEnemies No Mercy!” Amnesty, Criminality and Public Response in 1953', in P. Jones (ed.), $\underline{\text { The Dilemmas of De-Stalinization, Abingdon, 2006, pp. 21-40; M. Dobson, Khrushchev's }}$ Cold Summer: Gulag Returnees, Crime, and the Fate of Reform after Stalin, Ithaca, NY, 2009; N. Durmanov, ‘Amnistiia i pomilovanie po Stalinskoi konstitutsii’, $\underline{\text { Sovetskoe }}$ gosudarstvo i pravo, 1946, 5-6, pp. 44-52; and J. Hazard, 'What Soviet Amnesty Means', Foreign Policy Bulletin, 32, 1953, 16, pp. 1-2.

${ }^{133}$ N. Astaf'ev, V. Vishniakov, and O. Fin'kov, Politicheskaia amnistiia, Moscow, 1999; I. Marogulova, 'Pravovaia priroda amnistii i pomilovaniia', Sovetskoe gosudarstvo i pravo, 1991, 5, pp. 64-8; and S. Sabanin, ‘Amnistiia i pomilovanie v ugolovnom zakonodatel'stve Rossii', Gosudarstvo i pravo, 1995, 11, pp. 78-83.

${ }^{134}$ For a sense of the debate, see the various media articles posted by Johnson's Russia List, available at <http://russialist.org/?s=amnesty> [accessed 2 April 2014]. 